\title{
Alicja Zawistowska
}

UNIWERSYTET W BIAEYMSTOKU

E-MAIL: ZAWISTOWSKA.ALICJA@GMAIL.COM

\section{OSIĄGNIĘCIA EDUKACYJNE UCZNIÓW W WOJEWÓDZTWIE PODLASKIM NA TLE INNYCH REJONÓW POLSKI}

\section{Wstęp}

Wiele wskaźników służących do opisu rozwoju gospodarczego, efektywności rynku pracy czy inwestycji infrastrukturalnych wskazuje na istnienie zróżnicowania między regionami Polski. W społecznej świadomości wyraża się to podziałem na bogatszą Polskę A i biedniejszy wschód - Polskę B lub „ścianę wschodnią”. Ta ostatnia kojarzona jest $\mathrm{z}$ większym tradycjonalizmem, mniejszą zaradnością mieszkańców, a czasem nawet zacofaniem. Jednocześnie istnieje grupa wskaźników, w których to właśnie wschodnia część kraju wypada lepiej. Dotyczą one przede wszystkim pozaekonomicznych wymiarów jakości życia: niższego poziomu przestępczości, długości trwania życia czy niższego odsetka rozwodów. Niektóre z tych podziałów ukształtowały się w ostatnich dekadach, inne natomiast stanowią kontynuację tradycji powstałych w okresie zaborów lub jeszcze wcześniej. Efektem długiego trwania wyjaśnia się na przykład przestrzenne zróżnicowanie współczesnych zachowań i preferencji wyborczych [Zarycki 1996; Bartkowski 2003; Łukowski, Sadowski 2013], integracji społecznej czy zróżnicowanego poziomu przedsiębiorczości. Odniesieniami do tradycji historycznych wyjaśnia się również obserwowane współcześnie zróżnicowanie poziomu wykształcenia Polaków [Dzięcioł-Kurczoba 2015; Herbst 2007]. Dotychczasowe badania konsekwentnie pokazują, że mieszkańcy województw wschodnich, jeśli wyrażać to odsetkiem osób z wykształceniem wyższym, są słabiej wykształceni w porównaniu z mieszkańcami zachodniej części kraju [Herbst 2007]. Do odmiennych wniosków prowadzą natomiast analizy wyników egzaminów zewnętrznych. Wyniki testów przeprowadzanych pod koniec każdego progu szkolnego pozwalają stwierdzić, 
że uczniowie wschodnich i centralnych województw mają wyższe wyniki w porównaniu z uczniami zachodniej częścią kraju [Herczyński, Herbst 2002]. Innymi słowy, uczniowie „ściany wschodniej” lepiej radzą sobie z nauką w okresie szkolnym, ale dorosła populacja tego obszaru jest relatywnie słabiej wykształcona. W tym artykule kwestia ta zostanie omówiona dokładniej, a zróżnicowanie poziomu wykształcenia na poziomie województw zostanie zilustrowane danymi urzędowymi. Przedstawię również trzy funkcjonujące w literaturze hipotezy wyjaśniające te zróżnicowania.

Badania „geografii” osiągnięć edukacyjnych, których przykładem jest ten artykuł, wykorzystywane są między innymi w kontekście rozwoju regionalnego. W teoriach wzrostu gospodarczego, kapitał ludzki, którego kluczowym elementem jest formalne wykształcenie uważane jest za siłę napędową produktywności pracy czy możliwości absorbowania nowych rozwiązań w różnych dziedzinach rynku [Herbst 2007]. Poprzez odmienne zasoby kapitału ludzkiego, można wyjaśnić różnice w rozwoju między rejonami Polski na przełomie ostatniej dekady XX wieku i pierwszej dekady XXI wieku [Herbst 2007]. Przyjrzenie się strukturze wykształcenia mieszkańców województwa podlaskiego jest dodatkowo interesujące z perspektywy dokonujących się tam procesów demograficznych, a szczególnie depopulacji tego regionu.

\section{Struktura wykształcenia na poziome województw w Polsce}

Podstawowym wskaźnikiem geograficznego zróżnicowania wykształcenia Polaków jest odsetek osób z określonym poziomem wykształcenia. Interesować mnie będą skrajne fragmenty hierarchii edukacyjnej, a więc liczba osób z dyplomem studiów wyższych oraz tych, którzy skończyli naukę na poziomie co najwyżej gimnazjalnym. Według danych pochodzących z Narodowego Spisu Powszechnego Ludności i Mieszkań zebranych w 2011 roku przez GUS (wykres 1.) odsetek osób z wykształceniem wyższym w województwie podlaskim nie różnił się od krajowej przeciętnej i wynosił 16\%. Istotnie odstawał jedynie od województwa mazowieckiego, które jako główny ośrodek akademicki kraju skupiało największy odsetek osób z dyplomem studiów wyższych. Różnice między pozostałymi województwami były stosunkowo małe, ale dostrzegalne. W województwach: pomorskim, zachodniopomorskim, małopolskim, dolnośląskimi odsetek osób z wyższym wykształceniem był większy niż w województwach: „ściany 
wschodniej", czyli lubelskim, podlaskim, warmińsko-mazurskim. Relatywnie mniej osób z wyższym wykształceniem mieszkało też w podkarpackim, lubuskim, kujawsko-pomorskim, czy opolskim. Mniej dobrze wykształconych osób odnotowano więc nie tylko na wschodzie kraju, ale również w niektórych województwach leżących przy granicy zachodniej. Istotnym czynnikiem różnicującym może być tu nie tyle peryferyjne położenie, co obecność dużych miast. Wrocław, Kraków, Gdańsk czy Warszawa są ośrodkami, które nie dość, że dysponują własnymi absolwentami, to przyciągają również ludzi z innych rejonów kraju.

Odwrotnością tego jest „ranking” województw uporządkowany ze względu na odsetek osób z wykształceniem gimnazjalnym lub niższym. Otwiera go podlaskie, gdzie osoby te stanowiły $38 \%$ populacji objętej NSP. Było to kilka punków procentowych więcej niż w sąsiadującym województwie lubelskim (33\%) i niemal tyle samo co w województwie warmińsko-mazurskim (37\%).

Wykres 1. Odsetek osób z wykształceniem gimnazjalnym lub niższym niż gimnazjalne oraz wyższym w Polsce

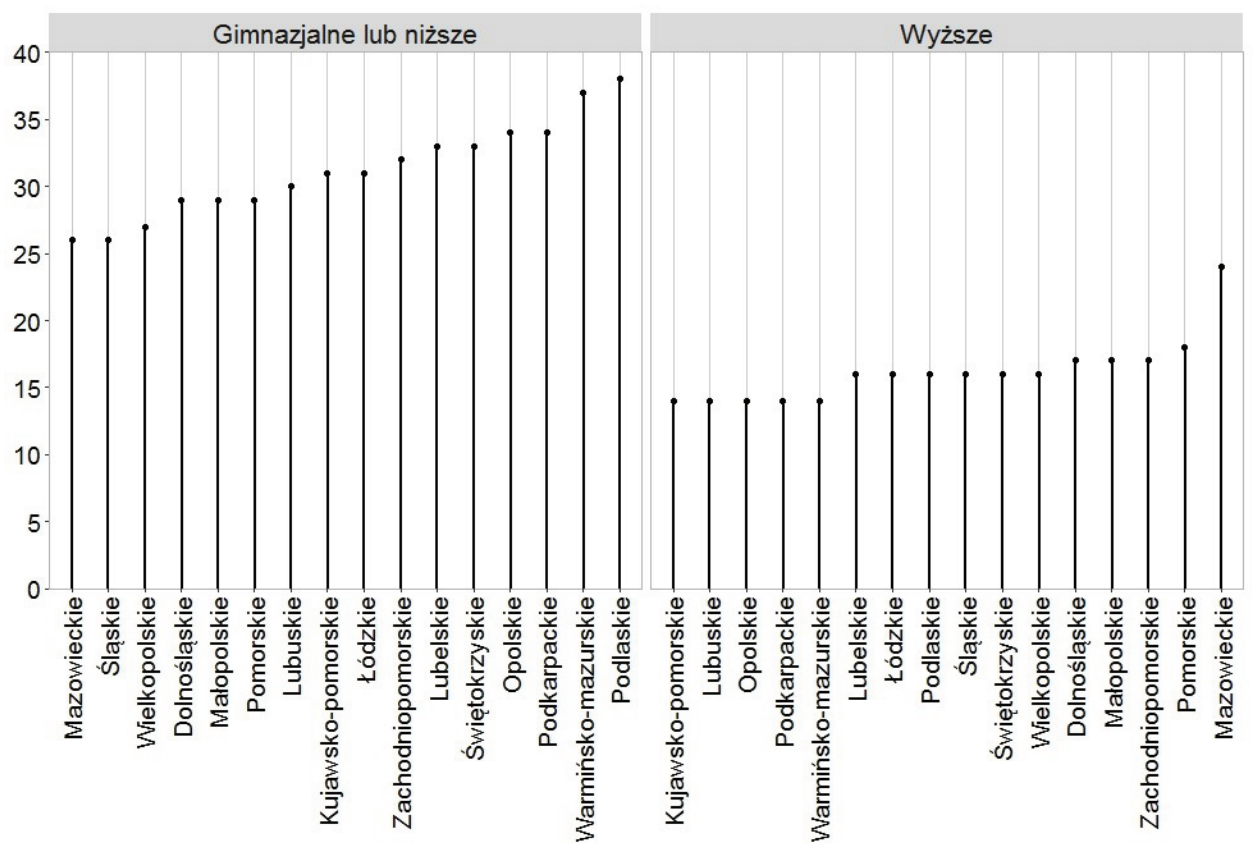

Źródło: Narodowy Spis PowszechnyLudności i Mieszkań 2011. 
Wśród czynników, które mogą mieć wpływ na to zróżnicowanie w pierwszej kolejności wskazać można fakt zamieszkiwania na wsi i w mieście (wykres 2). Na podlaskich wsiach odsetek osób, które zakończyły naukę na gimnazjum był największy w kraju i sięgał 50\% mieszkańców. W sąsiadującym województwie warmińsko-mazurskim sytuacja była zbliżona, ponieważ tam 47\% mieszkańców wsi miało wykształcenie gimnazjalne lub niższe. Powodem tak dużego odsetka słabo wykształconych osób, mogą być między innymi specyficzne uwarunkowania demograficzne, a więc niski poziom zaludnienia i starzenie się populacji. Bański i in. [2014] wskazuje, że we wschodniej część województwa podlaskiego i mazowieckiego oraz niektórych obszarach lubuskiego następują szczególnie szybkie procesy starzenia się populacji. Istnieje tu wyjątkowo duże w porównaniu $\mathrm{z}$ innymi rejonami nasycenie ludnością w wieku starszym, a równocześnie widoczny jest wyraźny ubytek ludności $\mathrm{w}$ wieku przedprodukcyjnym. Odpływ ludności jest szczególnie silny na wsiach - to właśnie tam koncentruje się duży odsetek osób starszych, które są jednocześnie najsłabiej wykształcone. W wielu gminach tego obszaru tylko 1\% mieszkańców ukończyło studia. $Z$ różnych powodów obszary te mają szczególnie dużą moc odpychania ludzi młodych, którzy grawitują w kierunku obszarów miejskich i podmiejskich w obrębie tych województw. W efekcie te ostatnie charakteryzują się wyraźnie korzystniejszą strukturą wykształcenia niż starzejące się wsie. We wschodniej Polsce wyróżnia się pod tym względem Białystok, Lublin czy Suwałki [Bański 2014].

Różnice w odsetku osób z wykształceniem wyższym na obszarach wiejskich nie był tak duże w skali kraju, jednak i tutaj województwo podlaskie obok kujawsko-pomorskiego, opolskiego i warmińsko-mazurskiego wyróżniało się na niekorzyść. W podlaskim istniała natomiast największa $\mathrm{w}$ porównaniu $\mathrm{z}$ innymi województwami luka między wsią a miastem pod względem odsetka osób z wykształceniem gimnazjalnym i niższym - wynosiła 21 punktów procentowych. Nieco niższa, ale również wysoka na tle kraju różnica istniała w województwie lubelskim i warmińsko-mazurskim. Potwierdza to, że główne miasta tych regionów szczególnie silnie przyciągają lepiej wykształcone osoby, a na wsiach pozostają te słabiej wykształcone.

Warto też wspomnieć o specyfice rynku edukacyjnego w Białymstoku. Głównie $\mathrm{z}$ powodu niżu demograficznego $\mathrm{w}$ ostatnich latach $\mathrm{w}$ mieście zamkniętych zostało kilka dużych wyższych uczelni niepaństwowych, a pozostałe $\mathrm{z}$ trudem walczą o utrzymanie się na rynku. Według danych 
GUS (Szkoły wyższe i ich finanse 2015) odsetek studentów na uczelniach niepublicznych zmalał tu o 60\% tylko między 2011 a 2015 rokiem. Ten sam problem dotyczy białostockich uczelni państwowych: Uniwersytet w Białymstoku i Politechnika Białostocka odnotowały w tym czasie spadek liczby studentów o nieco ponad 20\%. Zjawisko to nie jest jednak spowodowane jedynie zmniejszeniem się liczby studentów, ale ogólnym ochłodzeniem aspiracji maturzystów w całym kraju. Dane GUS pokazują bowiem, że od kilku lat współczynniki skolaryzacji „netto” i „brutto” zaczynają lekko, ale systematycznie spadać [GUS, Szkoły wyższe i ich finanse 2015]. W Białymstoku poziom aspiracji maturzystów, przynajmniej ten deklarowany, nadal utrzymuje się na wysokim poziomie. Z badań przeprowadzanych cyklicznie wśród maturzystów przez Instytut Socjologii UwB wynika, że w ciągu ostatnich lat prawie się nie zmienił: w 2010 roku na studia wybierało się 87\% maturzystów, a w 2015 - 86\% [Łukasz Wołyniec, w tym tomie].

Wykres 2. Odsetek osób z wykształceniem gimnazjalnym lub niższym i wyższym w podziale na wieś i miasto

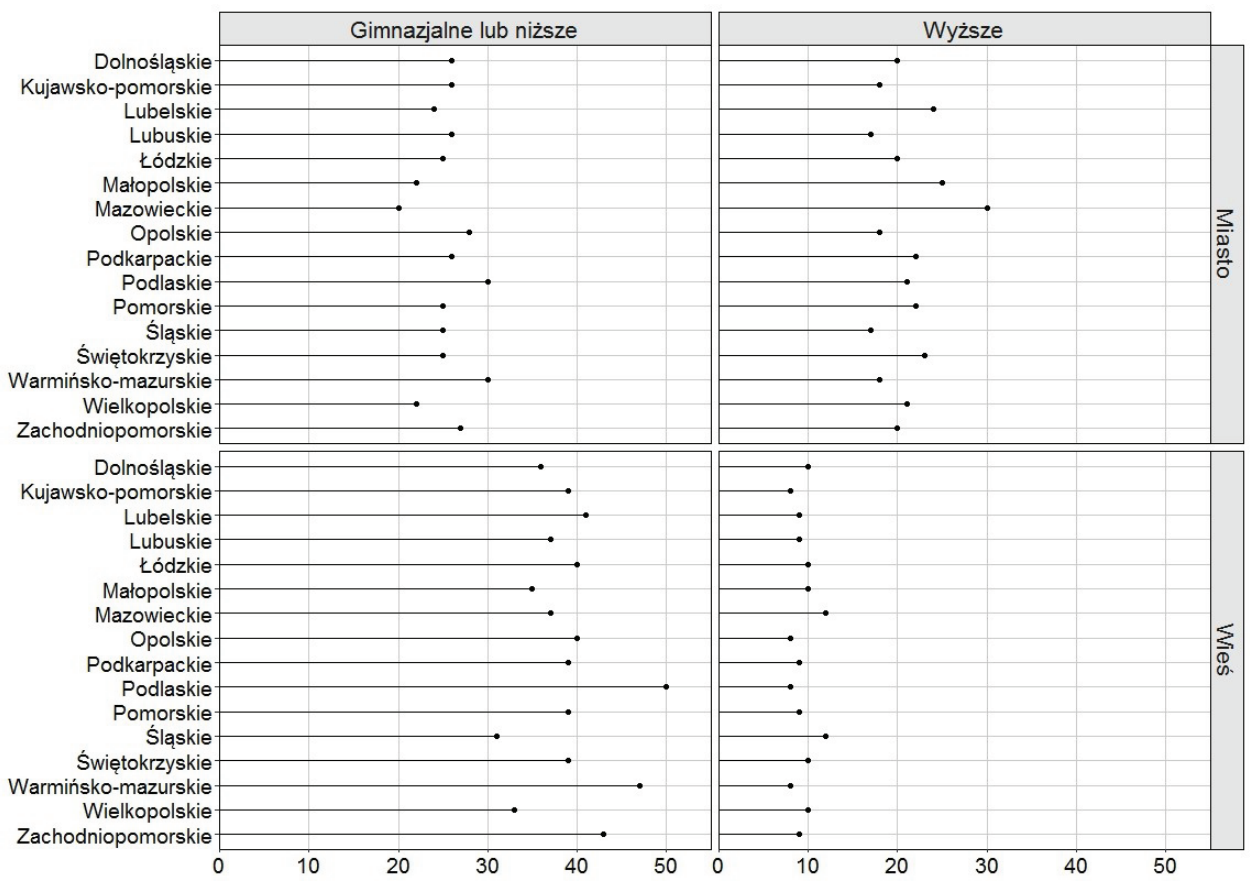

Źródło: Narodowy Spis Powszechny Ludności i Mieszkań 2011, tabela 11. 
Podsumowując ten fragment można wskazać, że na strukturę edukacyjną mieszkańców województwa podlaskiego wpływają typowe dla współczesnych społeczeństw ruchy migracyjne w kierunku większych miast. Czynnikiem specyficznym dla tego regionu jest głęboko zakorzenia świadomość, że przeniesienie się do dużego miasta i zdobycie wykształcenia jest formą awansu społecznego. Beata Borawska na marginesie badań karier edukacyjnych mieszkańców podlaskich wsi pisała, że dla osób wywodzących się $\mathrm{z}$ rodzin chłopskich i robotniczych w pierwszych latach po uzyskaniu niepodległości, zdobycie wykształcenia było najskuteczniejszy sposobem na strukturalny ruch „w górę" [Borawska 2006]. Nie była to ścieżka pewna, ponieważ w dużej mierze o możliwości „wybicia się" decydował selekcyjny charakter systemu edukacyjnego, ale powszechne przekonanie o szkole jako kanale społecznego awansu utrwaliło się na wsi. Andrzej Sadowski [2006] przypomina w tym kontekście o zmianie w percepcji wykształcenia mieszkańców Białegostoku. W latach 70. w społecznym wyobrażeniu funkcjonował podział na osoby „bez szkoły” oraz „po szkole”, przy czym do tej ostatniej kategorii zaliczano osoby $\mathrm{z}$ wykształceniem ponadpodstawowym [Sadowski 2006]. Niespełna trzy pokolenia później podział ten zastąpiony został przez osoby z wyższym wykształceniem i bez niego.

\section{Wyniki maturalne w województwie podlaskim na tle innych województw}

Obok wskaźników edukacyjnych dla całej populacji, o kapitale edukacyjnym mieszkańców regionu świadczą też wyniki uzyskane na egzaminach zewnętrznych. Analiza geograficznego zróżnicowania wyników egzaminów na niektórych szczeblach była już przedmiotem analiz innych badaczy [Herczyński, Herbst 2002; Czapniewski, Śleszyński 2007; Dzięcioł-Kuczbora 2015]. Badania pierwszej w historii Polski sesji egzaminów przeprowadzonych wśród gimnazjalistów i szóstoklasistów w 2002 roku przedstawili między innymi Jan Herczyński i Mikołaj Herbst [2002]. Wynikało z nich, że gminy leżące w północnej i zachodniej części Polski miały niższe wyniki niż gminy leżące w północno-wschodniej części kraju, a szczególnie $\mathrm{w}$ pasie przygranicznym. Interpretując te wyniki badacze obszernie nawiązali do historycznego podziału Polski na dzielnice rozbiorowe oraz powojenne ruchy migracyjne. Wśród czynników współczesnych autorzy wymienili między innymi wpływ zamożności mieszkańców powiatów oraz strukturę 
gospodarczą. Przykładowo, stopa bezrobocia na poziomie powiatu była negatywnie skorelowana $\mathrm{z}$ wynikami egzaminów, podobnie jak udział PGR przed 1989 rokiem. W przeciwny sposób oddziaływał poziom wpływów z podatku PIT - wyższe wpływy były związane z wyższymi wynikami, choć systematyczną różnicę obserwowano tylko w części humanistycznej na egzaminie gimnazjalnym oraz sprawdzianie szóstoklasisty [Herczyński, Herbst 2002].

Hipoteza o istnieniu korelacji między wynikami gimnazjalnymi a kulturowymi uwarunkowaniami została również potwierdzona dla wyników z 2006 roku. Analizy przeprowadzone przez Czapniewskiego i Śleszyńskiego [2007] potwierdziły, że powiaty północnej i zachodniej Polski miały przeciętnie niższe wyniki na egzaminie gimnazjalnym, niż południowej i wschodniej [Czapniewski, Śleszyński 2007]. Obok tego uniwersalne dla całej Polski okazały się zróżnicowania między miastem i wsią oraz wyższe wyniki w dużych miastach i powiatach je otaczających.

Wykresy 3 i 4 przedstawiają podstawowe wskaźniki dotyczące wyników maturalnych z 2016 roku. Spośród przedmiotów maturalnych, które mogli zdawać uczniowie, do analizy porównawczej wybrałam matematykę, informatykę oraz język angielski. Wiedzę z tego zakresu można uznać za komponenty kapitału ludzkiego, które szczególnie sprzyjają gospodarczemu rozwojowi indywidualnemu jednostek, ale również regionów. Oczywiście uwzględnienie tylko tych przedmiotów stanowi wąskie rozumienie najbardziej „rynkowych” kwalifikacji. Do nich zalicza się też dziedziny rozwijające kompetencje społeczne bądź artystyczne, jednak przedmioty takie jak filozofia, czy nauka o sztuce wybierane są przez maturzystów znacznie rzadziej niż pozostałe. Porównanie międzywojewódzkie pozwoli stwierdzić czy rozkład tych umiejętności jest w Polsce zbliżony, czy też istnieją regionalne „specjalizacje” i pewne miejsca na mapie są szczególnie zasobne w pewne typy kapitału.

Pierwszym i najbardziej ogólnym wskaźnikiem jest zdawalność egzaminów, a więc odsetek uczniów, którzy uzyskali co najmniej 30\% punktów na wszystkich egzaminach. W 2016 roku rozpiętość międzywojewódzka była stosunkowo niewielka, ale pewne odchylenia były widoczne. Województwo podlaskie lokowało się pod tym względem o dwa punkty procentowe ponad średnią ogólnopolską wynoszącą 79\%. Lepiej poradzili sobie tylko maturzyści z województwa lubuskiego, małopolskiego i mazowieckiego, gdzie odsetek sukcesów wynosił 82\%. Maturzyści z Podlasia korzystniej 
wypadli też na tle sąsiadów ze „ściany wschodniej”: w warmińsko-mazurskim maturę zdało 76\%, a w lubelskim 79\% uczniów. Do podobnych wniosków na temat geograficznego zróżnicowania prowadzą też analizy Dzięcioł-Kurczoby [2014] przeprowadzone dla roczników zdających maturę w latach 2005-2008. Wyższą zdawalność zaobserwowano w województwach centralnej i wschodniej Polski, a niższą na zachodzie i północy. Przekonuje to, że obserwacje dla roku 2016 nie są przypadkiem, ale trwałą tendencją.

Tabela 1. Zdawalność matury w powiatach województwa podlaskiego (w \%)

\begin{tabular}{|l|c|}
\hline $\begin{array}{c}\text { Zdawalność matury w powiatach } \\
\text { województwa podlaskiego }\end{array}$ & Procent \\
\hline m. Białystok & 86 \\
\hline sejneński & 84 \\
\hline wysokomazowiecki & 82 \\
\hline augustowski & 81 \\
\hline grajewski & 81 \\
\hline m. Łomża & 81 \\
\hline zambrowski & 80 \\
\hline m. Suwałki & 80 \\
\hline
\end{tabular}

\begin{tabular}{|l|c|}
\hline $\begin{array}{c}\text { Zdawalność matury w powiatach } \\
\text { województwa podlaskiego }\end{array}$ & Procent \\
\hline siemiatycki & 77 \\
\hline bielski & 75 \\
\hline hajnowski & 72 \\
\hline moniecki & 71 \\
\hline sokólski & 71 \\
\hline białostocki & 61 \\
\hline łomżyński & 56 \\
\hline suwalski & 45 \\
\hline
\end{tabular}

Źródło: OKE Łomża.

W tym miejscu warto też wspomnieć o wewnętrznym zróżnicowaniu województwa podlaskiego. Wyższą niż średnia wojewódzka zdawalność obserwować można wśród uczniów z Białegostoku oraz powiatu sejneńskiego, położonego w jego północnej części. Znacznie gorzej poradzili sobie uczniowie z powiatów położonych wokół dużych miast, czyli białostockiego, łomżyńskiego i suwalskiego. Różnice te wyjaśnić można po części procesami migracyjnymi zachodzącymi między większymi miastami (szczególnie Białymstokiem) a położonymi wokół nich podmiejskimi. Te ostatnie to gminy wiejskie lub wiejsko-miejskie, których najbardziej ambitna i ekonomicznie zasobna młodzież kontynuuje naukę w większych miastach. Dla 
bardziej zamożnej populacji stanowić mogą dobre miejsce do osiedlenia się, ale edukację na szczeblu średnim powierzają w ręce bardziej efektywnych liceów w Białymstoku, Suwałkach czy Łomży. Innym powodem jest mała oferta szkolna istniejąca poza większymi ośrodkami miejskimi. Przykładowo, w powiecie suwalskim w 2016 roku tylko jedna szkoła (zespół szkół) przeprowadzała egzamin maturalny. W szkole tej 45,5\% uczniów nie zdało matury.

W większych miastach województwa podlaskiego oczywiście również istniały szkoły, w których uczniowie poradzili sobie równie słabo, ale wojewódzka średnia zdawalności „podciągnięta” został przed dobre szkoły. Według raportu czasopisma „Perspektywy” z 2016 roku w województwie podlaskim, trzy najlepsze licea ogólnokształcące zlokalizowane były właśnie w Białymsto$\mathrm{ku}$, a czwarte w Łomży. Jednocześnie pierwsze najlepsze białostockie liceum było sklasyfikowane w rankingu „Perspektyw” jako 42 w kraju.

Uczniowie z Podlaskiego lepiej niż przeciętnie w kraju poradzili sobie również na obowiązkowym egzaminie maturalnym z matematyki (wykres 3). W 2016 roku średnia w kraju wynosiła 55\% punktów (na 100\% możliwych), natomiast uczniowie z Podlasia zdobyli przeciętnie 58\%. Uzyskali tym samym średnio o jeden punkt procentowy mniej niż maturzyści z podkarpackiego, mazowieckiego i małopolskiego, których wyniki były najwyższe w kraju i wynosiły przeciętnie 59\%. Dobre wyniki na maturze z matematyki w województwie podlaskim są szczególnie zasługą szkół, których uczniowie dobrze poradzili sobie również na egzaminach maturalnych $\mathrm{z}$ innych przedmiotów, choć w niektórych przypadkach widać pewną „specjalizację" w zakresie matematyki. Na przykład w dwóch najlepszych białostockich liceach uczniowie uzyskali ponad $80 \%$ punktów z tego przedmiotu, ale jednocześnie tylko około $65 \%$ z języka polskiego.

Nieco gorzej $\mathrm{w}$ porównaniu $\mathrm{z}$ innymi województwami Podlasianie poradzili sobie na egzaminie $\mathrm{z}$ matematyki na poziomie rozszerzonym. Przedmiot ten nie był obowiązkowy i uczniowie sami mogli zdecydować czy do niego przystąpią. Lepiej od uczniów z Podlasia poradzili sobie ich rówieśnicy z pięciu województw, a od uczniów z województwa mazowieckiego, które odnotowało najwyższe wyniki, dzieliły ich 4 punkty procentowe. Pozostali najbliżsi geograficznie sąsiedzi uzyskali niższe wyniki: uczniowie z warmińsko-mazurskiego 27\%, a lubelskiego 30\%. W przypadku tego egzaminu istniała też spora rozpiętość wyników między liceami w Białymstoku: najwyższy średni wynik szkoły wynosił $61,9 \%$, a najniższy niecałe $6 \%$. 


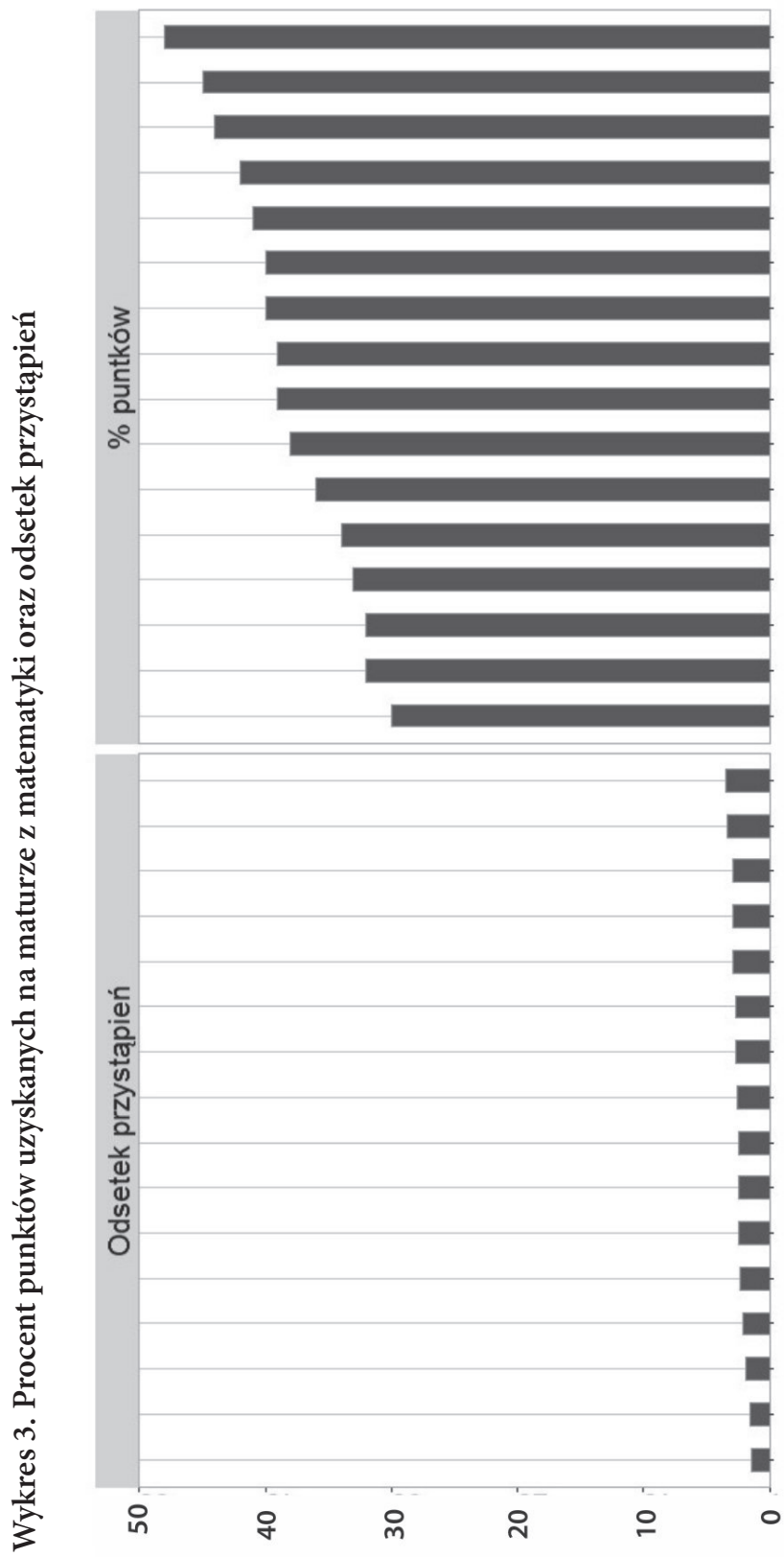

Kujawsko-pomorskie

Opolskie

Mazowieckie

Wielkopolskie

Podlaskie

Podkarpackie

Małopolskie

Śląskie

Pomorskie

Dolnośląskie

Świętokrzyskie

Łódzkie

Warmińsko-mazurskie

Lubuskie

Lubelskie

Zachodniopomorskie

Podlaskie

Dolnośląskie

Wielkopolskie

Opolskie

Kujawsko-pomorskie

Pomorskie

Podkarpackie

Zachodniopomorskie

Lubuskie

Śląskie

Mazowieckie

Warmijsko-mazurskie

Łódzkie

Lubelskie

Świętokrzyskie

Małopolskie 
Oprócz wyniku testu z matematyki na poziomie rozszerzonym, województwa różniły się między sobą pod względem odsetka uczniów, którzy do niego przystąpili. Przeciętnie w kraju 27\% uczniów spośród wszystkich maturzystów zdecydowało się zdawać ten egzamin, a wśród uczniów z województwa podlaskiego było to przeciętnie 30,4\% uczniów. W odróżnieniu od innych wskaźników, międzywojewódzka rozpiętość jest tutaj szczególnie duża. W województwie łódzkim egzamin ten zdawało $31 \%$ maturzystów (najwięcej), a w zachodniopomorskim 20\%. Bez dodatkowych analiz trudno wyjaśnić co stoi za tymi zróżnicowaniami. Być może pewien wpływ mają na to lokalne tradycje szkolne przejawiające się w ukierunkowaniu niektórych szkół na naukę tego właśnie przedmiotu.

Informatyka, która również była przedmiotem „do wyboru” na poziomie rozszerzonym, cieszyła się małym zainteresowaniem uczniów w skali kraju (wykres 4). W Polsce zdawało ten egzamin 2,5\% uczniów spośród wszystkich przystępujących do matury, ale to właśnie maturzyści z województwa podlaskiego zdawali go najchętniej (3,5\% uczniów). Co ciekawe $\mathrm{w}$ województwie podlaskim do egzaminu $\mathrm{z}$ tego przedmiotu przystąpiło relatywnie dużo dziewcząt, tj. $12,2 \%$. Nie jest to jednak udział najwyższy w kraju - ten odnotowano w województwie warmińsko-mazurskim $(13,5 \%)$. Przeciętne wyniki na maturze $\mathrm{z}$ tego przedmiotu lokują województwo podlaskie w środku rankingu wszystkich województw. Maturzyści z Podlasia uzyskali 41\% punktów, natomiast uczniowie z kujawsko-pomorskiego, którzy poradzili sobie najlepiej w kraju uzyskali $48 \%$.

Można domyślać się, że jakaś część tych różnic spowodowana jest dostępnością komputerów i szybkiego Internetu w szkołach. Istniejące statystyki są tutaj jednak bardzo pobieżne i ograniczają się tylko do najbardziej ogólnych informacji na poziomie województw, a nawet te dane mają charakter szacunkowy i nie są aktualne. Pewnym przybliżeniem poziomu komputeryzacji z 2013 roku w liceach ogólnokształcących są dane zawarte w tabeli 2. Zawiera ona liczbę uczniów przypadających na jeden komputer posiadający dostęp do Internetu oraz korzystających z szybkiego łącza. Województwo podlaskie znalazło się pod względem tego pierwszego wskaźnika na ostatnim miejscu - na jeden komputer $\mathrm{z}$ dostępem do szerokopasmowego Internetu przypadało ponad 20 uczniów. W sąsiadującym województwie mazowieckim 16,3, a warmińsko-mazurskim 18. Sytuacja województwa podlaskiego wygląda nieco korzystniej, gdy mowa jest ogólnie o komputerach z dostępem do Internetu. Tutaj zresztą w porównaniu do tego pierwszego wskaźnika województwa są znacznie mniej zróżnicowane. Czynnikiem mocniej różnicującym współczesne szkoły jest zatem dostęp do szybszego Internetu, a nie Internetu w ogóle. 
Wykres 4. Odsetek przystąpień do matury z informatyki oraz wyniki z egzaminu w 2016 roku



Źródło: obliczenia własne na podstawie danych CKE.

Na marginesie warto wspomnieć, że liczba komputerów dość wyraźnie zależna jest od typu szkoły. GUS podaje, że w roku 2013/14 - 76\% szkół licealnych miało dostęp do komputerów, w technikach było to $85 \%$, w liceach profilowanych 50\%, a szkołach zasadniczych zawodowych zaledwie $32 \%$.

Wydaje się zatem, że wpływ infrastruktury komputerowej na wybieralność informatyki na maturze jest ograniczony. Prawdopodobne jest, że większą rolę odgrywać może, podobnie jak w przypadku innych przedmiotów wybieranych dobrowolnie, efektywność kształcenia. Nauka programowania, czy tworzenia algorytmów wymaga oczywiście odpowiedniego sprzętu, ale bez właściwego „opakowania” tej wiedzy, może to nie wystarczyć. Innym ważnym czynnikiem, który może odgrywać rolę są sygnały pochodzące $z$ otoczenia ucznia.

W przypadku Podlasia bodźcem zachęcającym do zdawania informatyki mogły być międzynarodowe sukcesu odnoszone w ostatnich latach przez studentów Politechniki Białostockiej, które były szeroko opisywane w lokalnych mediach. Wśród maturzystów istnieje również powszechna opinia, że ten kierunek kształcenia wiąże się $\mathrm{z}$ atrakcyjnymi profitami na rynku pracy. 
Tabela 2. Wskaźniki dostępu do Internetu w liceach ogólnokształcących w roku 2013 w województwach

\begin{tabular}{|l|c|}
\hline \multicolumn{2}{|c|}{$\begin{array}{c}\text { Liczba uczniów przypadających na jeden } \\
\text { kzomprokopasmowego }\end{array}$} \\
\hline opolskie & 10,3 \\
\hline świętokrzyskie & 12,5 \\
\hline lubuskie & 12,9 \\
\hline zachodniopomorskie & 13,0 \\
\hline lubelskie & 13,5 \\
\hline kujawsko-pomorskie & 15,6 \\
\hline mazowieckie & 16,3 \\
\hline małopolskie & 16,5 \\
\hline łódzkie & 16,6 \\
\hline dolnośląskie & 17,6 \\
\hline warmińsko-mazurskie & 18,0 \\
\hline wielkopolskie & 19,2 \\
\hline podkarpackie & 19,7 \\
\hline śląskie & 20,5 \\
\hline pomorskie & 19,6 \\
\hline podlaskie & 19,1 \\
\hline
\end{tabular}

\begin{tabular}{|l|c|}
\hline \multicolumn{2}{|c|}{$\begin{array}{c}\text { Liczba uczniów przypadających na jeden } \\
\text { komputer z dostępem do Internetu }\end{array}$} \\
\hline opolskie & 8,5 \\
\hline lubuskie & 10,4 \\
\hline lubelskie & 10,9 \\
\hline zachodniopomorskie & 11,0 \\
\hline świętokrzyskie & 11,6 \\
\hline podlaskie & 12,1 \\
\hline mazowieckie & 12,3 \\
\hline małopolskie & 12,4 \\
\hline warmińsko-mazurskie & 12,5 \\
\hline dolnośląskie & 12,6 \\
\hline kujawsko-pomorskie & 12,8 \\
\hline łódzkie & 13,0 \\
\hline podkarpackie & 15,0 \\
\hline wielkopolskie & 15,3 \\
\hline śląskie & 15,8 \\
\hline pomorskie & 13,0 \\
\hline
\end{tabular}

Źródło: analizy własne na podstawie danych GUS.

Ostatnim porównywanym przedmiotem jest matura z języka angielskiego na poziomie rozszerzonym. W odróżnieniu od informatyki różnice międzywojewódzkie były tu małe, a uczniowie wszystkich województw zdali ten test na poziomie 50\% - 60\%. Mieszkańcy Podlasia zdobyli 56\%, znów nieco więcej niż sąsiedzi z północy i południa, ale mniej niż uczniowie 
z województwa mazowieckiego. Brak zróżnicowania wyników jest prawdopodobnie związany z powszechnością nauczania tego języka w kraju. W województwie podlaskim nauką języka angielskiego objętych było w 2015 roku 98,7\% uczniów w wieku szkolnym (chodzi o wszystkie szczeble). Teoretycznie zatem prawie każdy Podlasianin, który w ostatnich latach przeszedł cykl szkolny powinien władać językiem angielskim. W województwie podlaskim znacznie mniej powszechne było z kolei nauczanie języka niemieckiego. Objętym było nim 25,3\% uczniów - najmniej spośród pozostałych województw. Język ten, zapewne ze względu na sąsiedztwo jest szczególnie popularny w zachodnich województwach: w zachodniopomorskim (48,6\%), dolnośląskim (46,9\%), a szczególnie lubuskim $(54,9 \%)$. Zasada bliskości geograficznej nie sprawdza się w takim samym stopniu w województwach leżących przy wschodniej granicy. W województwie podlaskim nauką języka rosyjskiego objętych zostało najwięcej uczniów w kraju, ale mimo to, stanowili oni tylko $15,2 \%$ uczniów [GUS, Oświata i wychowanie 2015]. Poza językami kongresowymi, specyfiką województwa podlaskiego jest nauczanie w języku białoruskim. W całym województwie do matury z tego przedmiotu przystąpiło 198 uczniów na poziomie podstawowym i 16 na poziomie rozszerzonym. Odsetek sukcesów na tym pierwszym wynosił $99 \%$.

Obraz, który wyłania się z zebranych danych jest koherentny z wnioskami płynącymi $\mathrm{z}$ innych badań na temat geograficznego zróżnicowania wyników egzaminów zewnętrznych. Województwa można podzielić „Z grubsza” na dwie grupy. Do jednej należą województwa południowej, centralnej i wschodniej Polski (małopolskie, mazowieckie, podlaskie, łódzkie, podkarpackie, świętokrzyskie) z wyższymi wynikami, a do drugiej - zachodnie, gdzie wyniki są nieco niższe. Nie jest to jednak sztywną regułą, ale raczej przybliżeniem zróżnicowań. Nasilenie różnic uzależnione jest również od przedmiotu - spośród porównywanych przedmiotów najwyraźniejszy trend widoczny jest $\mathrm{w}$ przypadku egzaminu $\mathrm{z}$ matematyki, ale rozmywa się w przypadku informatyki i znika na maturze $\mathrm{z}$ języka angielskiego. Być może podziały byłyby ostrzejsze, gdyby analiza objęła wyłączenie egzaminy zdawane na poziomie podstawowym, a więc obowiązkowe dla wszystkich. Na wybór przedmiotów rozszerzonych większy wpływ mogą mieć bowiem czynniki związane z efektywnością konkretnej szkoły, kwalifikacjami kadry czy szkolną tradycją.

Wyraźnie słabiej natomiast województwo podlaskie oraz pozostałe leżące w części wschodniej wypadają w porównaniu z poziomem wykształcenia dorosłej populacji. Charakteryzują się niższym odsetkiem osób, 
które ukończyły studia i jednocześnie posiadają nadreprezentację osób słabiej wykształconych. Najwyraźniej wschodnia część kraju tworzy dobre warunki instytucjonalne do zdobywania wiedzy bądź istnieją tu silniejsze bodźce skłaniające do bardziej intensywnej nauki na etapie obowiązkowego cyklu. Potem jednak ten kapitał znika. Dalsze etapy kariery edukacyjnej realizowane są w województwach centralnej i zachodniej Polski, a absolwenci lokalnych uczelni wyższych chętnie migrują za pracą do bardziej rozwiniętych ekonomicznie regionów kraju lub poza nim.

Hipotezy zróżnicowania osiągnięć edukacyjnych

Wskazane powyżej zróżnicowanie poziomu wykształcenia między województwami wyjaśnić można kilkoma współwystępującymi ze sobą procesami. Jednym $\mathrm{z}$ ważniejszych są wspomniane wcześniej migracje. Chodzi tu zarówno o wyjazdy osób, które są już dobrze wykształcone, a poszukują wyższego standardu życia w centralnej lub zachodniej Polsce, ale również o migracje maturzystów pragnących zdobyć dyplom uczelni innej niż lokalna. Beata Huk [2010] zwraca uwagę, że bardziej ambitni uczniowie już w gimnazjum rozważają wyjazd ze stolicy Podlasia. Natomiast dla młodzieży z okolicznych miejscowości, Białystok, jak twierdzi badaczka, stał się tylko przystankiem na drodze do realizacji kariery w większych ośrodkach. Wynika to między innymi z powszechnego wśród uczniów przekonania, że jakość lokalnej oferty akademickiej nie daje dobrych perspektyw zawodowych. Dla młodych ludzi motywem nie bez znaczenia jest też chęć „wyrwania się" z prowincji. Oczywiście z możliwości tej skorzysta tylko pewna frakcja uczniów pochodząca z zamożniejszych rodzin. Dla pozostałych ważnym kryterium wyboru uczelni staje się geograficzna bliskość od szkoły średniej [Herbst 2009a]. W takich miastach jak Białystok, Łódź, Rzeszów czy Katowice odsetek lokalnych studentów szacowany był w na 80\% [Herbst 2009a]. W sytuacji niżu demograficznego, z którym nierzadko idzie w parze obniżenie selektywności uczelni - również tych bardziej prestiżowych, mechanizmy wypychające maturzystów poza rodzime ośrodki mogą działać jeszcze silniej na młodzież z wyższymi wynikami na maturze. Kierunkiem szczególnie atrakcyjnym dla mieszkańców województwa podlaskiego i Białegostoku jest Warszawa. Oprócz tego, że miasto to przyciąga maturzystów z różnych rejonów kraju, ma też dużo większy odsetek „zatrzymań” napływowych studentów, którzy po uzyskaniu dyplomu nie wracają do rodzinnego miasta. Dla porównania można podać, że w Białymstoku odsetek „Zatrzymań" wynosił 16\%, a w Warszawie kształtował się na poziomie 35\% 
[Herbst 2009a]. Względnie wysokie wyniki uzyskiwane przez maturzystów z Podlasia stanowią swojego rodzaju rezerwuar kapitału ludzkiego dla innych miast, głównie Warszawy. Do chwili ukończenia szkoły średniej uczniowie korzystają z lokalnej oferty edukacyjnej, ale miasto nie potrafi zatrzymać tych najbardziej zdolnych, co przekłada się na relatywnie niski udział osób z wyższym wykształceniem. Oczywiście problem odpływu wykształconych osób dotyczy wszystkich regionów leżących poza centrum, jednak w województwie podlaskim jest on dodatkowo wzmocniony lokalną sytuacją demograficzną [por. Bański i in. 2014].

\section{Nieuczciwość egzaminacyjna a wyniki egzaminacyjne}

Przewagę mieszkańców pasa województw wschodnich i centralnych na egzaminach zewnętrznych rozpatruje się czasem przez pryzmat nieuczciwości egzaminacyjnej [zob. Herbst 2009b]. Spekuluje się, że za geograficznymi różnicami w wynikach stoją odmienne warunki przeprowadzania testów, a dokładniej większe nasilenie oszustw egzaminacyjnych w regionach występowania wyższych wyników. Problem uczciwości egzaminacyjnej oraz jego wpływ na wyniki podniesiony został w 2002 roku, gdy po zakończeniu pierwszego w historii Polski zewnętrznego egzaminu gimnazjalnego do Centralnej Komisji Egzaminacyjnej napływały liczne zgłoszenia o naruszeniu procedury zdawania testów. Chodziło zarówno o przyzwolenie uczniom na odpisywanie od siebie, jak również niedopuszczalną pomoc uczniom ze strony nauczycieli. Dyskusja na ten temat dotyczyła między innymi Krakowa, gdzie z powodu podejrzeń o powszechność oszustw, w niektórych szkołach przeprowadzono dodatkowe analizy testów. Potwierdziły one przypuszczenia, że wyższe wyniki były efektem ściągania. Przykładem była jedna ze szkół, w której wśród uczniów piszących w tej samej sali najpierw połowa wybrała ten sam dystraktom, a potem zmieniła odpowiedź na poprawną [Tyralska-Wojtycza, Widur, Boba 2006]. Badanie sondażowe mające na celu określenie skali tego zjawiska przeprowadzone wśród maturzystów Krakowa w roku 2003 potwierdziło, że ponad 80\% uczniów przyznało się do ściągania na sprawdzianie, jeśli ma taką możliwość. Odpowiedzi te nieznacznie różniły się między uczniami różnych typów szkół maturalnych, zewnętrzną i wewnętrzną motywacją do nauki, a nawet wynikami uzyskanymi na egzaminie gimnazjalnym [Lipska 2006].

Nie ma jednak wystarczających dowodów, aby przypadek krakowski z 2002 roku rozciągać na cały kraj i traktować jako trwały trend. O zróżnicowaniu geograficznym nieuczciwości egzaminacyjnej przekonująco nie 
informują dane urzędowe tworzone na podstawie formalnych zastrzeżeń obserwatorów egzaminacyjnych, uczniów lub nauczycieli. Częstość tych zgłoszeń zbyt zależna jest od indywidualnych decyzji nauczycieli sprawdzających testy, aby można było je potraktować jako rzetelną informację o wykroczeniach egzaminacyjnych. Przykładowo, częstość zastrzeżeń egzaminatorów co do niesamodzielności prac uczniów na maturze w 2005 roku wahała się od $6 \%$ (odnotowanych w OKE w Jaworznie) do 16,5\% (stwierdzonych w OKE łódzkim).

Ściąganie jako jedna z przyczyn wyższych wyników w centralnej i wschodniej Polsce wydaje się dyskusyjne i przy obecnym stanie badań trudno znaleźć przekonujące dowody na poparcie tej tezy. Przyzwolenie na ściąganie musiałoby bowiem różnicować wyniki zarówno egzaminów szóstoklasistów, gimnazjalnych, jak i maturalnych, ponieważ w przypadku wszystkich trzech widoczne są zróżnicowania terytorialne. Oszustwa musiałyby być wspólnym doświadczeniem szkół okolic krakowskich, sandomierskich i białostockich, które leżą „w pasie” wyższych wyników. Jeśli hipoteza o zróżnicowanej geograficznie tolerancji na fałszerstwa okazałby się prawdziwa, oznaczałoby to, że wyniki uczniów ze środkowej i wschodniej Polski słabiej przewidują ich prawdziwą wiedzę niż wyniki uczniów z rejonów Polski zachodniej. Oznaczałoby to innymi słowy, że wyniki egzaminacyjne byłyby zbyt wysokie $\mathrm{w}$ porównaniu $\mathrm{z}$ ich faktyczną wiedzą. Taka „inflacja” mogłaby się przejawiać na różne sposoby, między innymi większymi niepowodzeniami na studiach lub wyborem studiów mniej selektywnych przy kontroli innych czynników.

\section{Wpływ tradycji kulturowej}

Wyjazdy maturzystów i absolwentów lokalnych uczelni poza województwo nie wyjaśniają geograficznego zróżnicowania wyników egzaminów zewnętrznych. Badacze zajmujący się geograficznym zróżnicowaniem różnego rodzaju zachowań społecznych, również stosunkiem do wykształcenia, proponują, aby odpowiedzi poszukać w kulturowych procesach długiego trwania [Herbst i Herczyński 2002; Dzięcioł-Kurczoba 2014; Bartkowski 2003]. Nałożenie wyników egzaminów zewnętrznych na mapę przedwojennej Polski pozwala zauważyć, że wyższe wyniki pojawiają się częściej na terenie dawnej Kongresówki i Galicji, a gorzej radzą sobie uczniowie z obszarów należących do dawnego zaboru pruskiego. Jak zauważają [Herbst, Herczyński 2002] ziemie zachodnie i północne były obszarami o zbliżonych do siebie i przeciętnie niższych wynikach na tle pozostałych 
historycznych dzielnic, a na ich obszarze wyróżniały się tylko duże miasta takie, jak Wrocław czy Trójmiasto [Herbst, Herczyński 2002].Wyższe wyniki egzaminów zewnętrznych pojawiają się zatem w regionach, które w przeszłości były mniej rozwinięte gospodarczo. Królestwo i Galicja na przełomie XIX i XX wieku charakteryzowały się największym poziomem analfabetyzmu oraz mniejszym dostępem do oświaty niż Wielkopolska, Pomorze i Ziemie Odzyskane [Bartkowski 2003]. Związane to było z ogólnie mniejszą modernizacją tych rejonów wyrażaną choćby dostępem do codziennych dóbr (wyposażenie domów, materiały z jakich były budowane, elektryfikacja), urbanizacji (gęstość linii kolejowych) i poziomu ubóstwa. Co ciekawe jednak, fakt ograniczonego dostępu do instytucji oświatowych w Królestwie nie powstrzymywał części zamieszkującej tam ludności przed nielegalnym nauczaniem domowym, które zgodnie $\mathrm{z}$ oficjalnymi danymi przybierało charakter masowy i objęło 1/3 ludności. Mimo tych prób samodzielnego nadrabiania zaległości różnice między regionami odnotowane w trakcie spisu z 1931 roku były istotne [Bartkowski 2003]. Zdaniem Bartkowskiego na wysoki poziomu analfabetyzmu tego regionu wpłynęła na przede wszystkim bieda. Inna sytuacja panowała w zaborze pruskim. Wielkopolska i Pomorze charakteryzowały się lepszym dostępem do infrastruktury, również szkolnej. Bartkowski [2003] pisze, że w zaborze tym analfabetyzm nie miał charakteru masowego, istniała tam dobrze rozwinięta sieć czytelni, a piśmiennictwo skierowane do ludu cieszyło się dużą popularnością. Te działania proedukacyjne miały wsparcie lokalnych elit, dla których były sposobem na kształtowanie świadomości narodowej. Paradoksalnie jednak, wyższy poziom gospodarczej modernizacji nie musi sprzyjać przedłużonym karierom szkolnym. Istnienie atrakcyjnych alternatyw pozaedukacyjnych może negatywnie wpływać na przekonanie o sensie kształcenia.

Jeśli szukać źródeł współczesnych zróżnicowań edukacyjnych w tradycjach ukształtowanych na przełomie XIX i XX wieku, to istotną rolę odgrywają tutaj również skutki dwóch przeciwstawnych zjawisk: migracji i zasiedziałości. Ludność Ziemi Zachodnich i Północnych kraju stanowili przesiedleńcy, repatrianci i migranci z różnych stron kraju. Amalgamat ten - jak pisze Bartkowski [2003] - wyróżniał się na tle kraju szczególną zdolnością adaptacji do nowych warunków, akceptacji odmienności czy innowacyjności i przedsiębiorczości. Jednak obok tej otwartości, koniecznej $\mathrm{w}$ zetknięciu $\mathrm{z}$ nowym środowiskiem, równolegle pojawiły się procesy niesprzyjające dłuższym inwestycjom w edukację. Migracje oznaczały jednak przede wszystkim przerwanie międzypokoleniowej transmisji wartości. 
Chodzi nie tylko o utratę przeświadczenia, że edukacja stanowi istotną wartości, ale o towarzyszące osadnikom trwałe poczucie tymczasowości. Bartkowski [2003] cytuje badania, z których wynika, że osadnicy często zmieniali mieszkania, nie inwestowali $\mathrm{w}$ nie, byli bardziej niż $\mathrm{w}$ Polsce centralnej skłonni do sprzedania ziemi. Panowała obawa o utratę posiadanych dóbr oraz niechęć do ich kumulowania. Słabsza na „Ziemiach Odzyskanych" była też więź lokalna, między mieszkańcami istniało poczucie obcości. Naruszenie struktury społecznej doprowadziło też do podważania dawnych autorytetów, z czym wiązała się większa tolerancja wobec patologii, między innymi rozwodami czy przestępczością. Czy wobec powszechnego poczucia tymczasowości, osłabionego kapitału społecznego możliwe było planowanie długofalowych inwestycji w edukację? Współczesne badania edukacyjne dają na to pytanie jednoznaczną odpowiedź. Teoria kapitału społecznego wyjaśnia, że silne więzi lokalne, poczucie stabilność oraz świadomość istnienia sankcji i ugruntowane normy tworzą odpowiedni grunt do budowania stabilnych karier szkolnych. Podkreślić jednak należy, że to nie sam fakt bycia migrantem wiąże się $\mathrm{z}$ ryzykiem szybszego wypadania $\mathrm{z}$ edukacji. Wnioski z badań przeprowadzonych wśród współczesnych migrantów mówią, że to właśnie przybysze osiągają lepsze wyniki w testach szkolnych niż autochtoni, miedzy innymi za sprawą silnych więzi rodzinnych, które tworzyły względnie zamknięte wspólnoty [Mikiewicz 2011]. Zatem ciągłość tradycji i silne więzi tworzą bardziej stabilny grunt do rozwoju dłuższych karier szkolnych. Takie warunki istniały w Galicji. Konserwatyzm, trwałość małomiasteczkowych więzi, zasiedziałość, czy niski stopień rozwoju gospodarczego tego obszaru sprzyjał dłuższej edukacji. Nie bez powodu obszar ten stał się zapleczem powojennej kadry oświatowej i administracyjnej. Bartkowski [2003] przytacza dane wskazujące, że prawie 2/5 wszystkich nauczycieli szkół średnich w Polsce niepodległej i ponad 1/3 pracowników służby cywilnej pochodziło właśnie z Galicji.

Innym wyjaśnieniem zróżnicowań geograficznych wyników jest dostępność pozaedukacyjnych ścieżek kariery. Większa liczba miejsc pracy w zakładach czy przedsiębiorstwach może zachęcać część absolwentów gimnazjów do wcześniejszego wychodzenia z systemu edukacji i wybierania szkół przegotowujących do zawodu. Więcej uczniów skróconego cyklu nauki można spodziewać się zatem tam, gdzie rynek pracy dla wykwalifikowanych pracowników jest bogatszy. Na to właśnie wskazują dane. W rejonach zachodniej Polski, Pomorzu, Śląsku i Dolnym Śląsku, a więc tam, gdzie wyniki egzaminów są niższe odsetek pracujących w sektorze przemysłu jest przeciętnie wyższy niż średnia w Polsce oraz wyższy niż we 
wschodniej części Polski i południu. Ponadto, sąsiedztwo z rozwiniętym gospodarczo sąsiadem sprawia, że mieszkańcy zachodniej części Polski częściej niż ich rówieśnicy z centrum kraju i rejonów wschodnich stoją przed dylematem wyjazdów zarobkowych na Zachód. Podobne decyzje podejmują również ich rodzice, których wpływ na rozwój edukacyjny dzieci jest niebagatelny. Badania nad migracjami przeprowadzone wśród rodziców pokazują, że obszary najbardziej intensywnych migracji pokrywają się w pewnym zakresie z mapą niższych wyników. Doświadczenia migracyjne mieli najczęściej rodzice $\mathrm{z}$ województwa opolskiego, zachodniopomorskiego, warmińsko-mazurskiego, świętokrzyskiego i podkarpackiego [Walczak 2008]. Skutki wyjazdów rodzicielskich dla karier edukacyjnych dzieci są na ogół niekorzystne. Walczak [2008] wymienia wśród nich wzrost absencji szkolnych czy pojawienie się różnorodnych zachowań patologicznych, choć ich istnienie wśród dzieci migrantów nie jest wyłączenie efektem wyjazdów. Na migrację, jako czynnik silniej powiązany z niższymi wynikami maturalnymi uczniów zwraca natomiast uwagę Dzięcioł-Kurczoba [2015]. Doświadczenia migracyjne wiążą się nie tylko z ryzykiem przerwania nauki, ale sprzyjają też wytworzeniu się niższych aspiracji. Do innych czynników zaliczyć można związane z migracjami rozbicie rodzin, czy brak kontroli społecznej nad dziećmi.

\section{Podsumowanie}

Struktura edukacyjna województwa podlaskiego jest kształtowana przez kilka czynników. Na najbardziej ogólnym poziomie wpływają na nią uwarunkowania gospodarcze oraz demograficzne regionu. Niski poziom urbanizacji, słabe zaludnienie oraz brak ważnych ośrodków ekonomicznych sprawiają, że edukacja staje się istotną, jeśli nie jedyną strategią życiową młodych ludzi, szczególnie mieszkańców wyludniających się wsi i małych miasteczek. Perspektywa „wyrwania się" z miasta leżącego na peryferiach może być dla części uczniów ważnym bodźcem pobudzającym aspiracje. Choć w ostatnich latach Białystok zadbał o rozwój instytucji kulturalnych oraz poczyniono kilka ważnych inwestycji ekonomicznych, opinia o Białymstoku, jako mieście oferującym mniejsze możliwości rozwoju zawodowego niż Warszawa czy Wrocław, jest wśród młodych mieszkańców powszechna. Można uznać to za jeden z ważniejszych czynników wypychający część młodych ludzi poza region i w konsekwencji prowadzący do „drenażu mózgów”. Nie jest to jednak zjawisko ani o zasięgu regionalnym, ale stanowi element globalnego trendu obserwowanego na świecie. Z punktu widzenia 
regionalnej polityki publicznej istotne jest więc tworzenie możliwie najlepszych warunków do realizacji karier zawodowych i życiowych tej części absolwentów, którzy decydują się rozstać.

\section{Bibliografia}

Bański J. i in. (2014), Współczesne przekształcenia społeczno-gospodarcze a potencjał ludnościowy Polski wschodniej. Studia obszarów wiejskich, t. 34, [dostęp: 11.01.2017].

Bartkowski J. (2003). Tradycja i polityka: wpływ tradycji kulturowych polskich regionów na współczesne zachowania społeczne i polityczne, Warszawa.

Borawska B. (2006). Ja siebie nie widziałam na wsi:(o awansie edukacyjnym młodzieży wiejskiej w okresie zmiany systemowej), Białystok.

Czapiewski K. Ł., Śleszyński P. (2007), Geografia zróżnicowania wyników egzaminów zewnętrznych, „Egzamin. Biuletyn Badawczy CKE”, nr 11.

Dzięcioł-Kurczoba B. (2015). Zróżnicowanie przestrzenne i uwarunkowania wyników matury $w$ Polsce $w$ latach 2005-2008 oraz 2010-2014, Łódź.

Herbst M. (2007), Kapitał ludzki i kapitał społeczny a rozwój regionalny. Warszawa.

Herbst M. (2009a),Tworzenie $i$ absorpcja kapitału ludzkiego przez miasta akademickie $w$ Polsce, „Studia Regionalne i Lokalne”, nr 4.

Herbst M. (2009b), Mierzenie jakości kapitału ludzkiego a nieuczciwość edukacyjna, „Psychologia Społeczna", t. 4, s. 1-2.

Herczyński J., Herbst M. (2002), Pierwsza odsłona: społeczne i terytorialne zróżnicowanie wyników sprawdzianu szóstoklasistów i egzaminu gimnazjalnego przeprowadzonych wiosna 2002 roku: raport przygotowany na zlecenie Fundacji Klub Obywatelski, Warszawa.

Huk B. (2010), Aspiracje migracyjne młodzieży na przykładzie badań młodzieży uczacej się w Białymstoku, „Pogranicze. Studia Społeczne”, t. 16

Lipska M. (2006), Uczciwość egzaminacyjna przyszłych „nowomaturzystów”. Wyniki badań Pracowni Ewaluacji CKE z września 2003 r., „Egzamin”, nr 7.

Łukowski W., Sadowski I. (2013), Podział społeczno-polityczny w Polsce. Kilka uwag teoretycznych, „Studia Politologiczne”, t. 29, s. 11-36.

Mikiewicz P. (red.) (2011), Kapitał społeczny i edukacja. Badanie porównawcze pomiędzy Polska i Islandia. Raport podsumowujący, Wrocław.

Narodowy Spis PowszechnyLudności i Mieszkań 2011.

Sadowski A. (2006), Białystok. Kapitał społeczny mieszkańców miasta, Białystok.

Sołdra-Gwiżdż T. (2008), Edukacja w wielokulturowej społeczności Opolszczyzny, [w:] Ślązacy, Kaszubi, Mazurzy i Warmiacy - między polskością, a niemieckością, red. A. Sakson, Poznań. 
Slany K., Ślusarczyk M. (2013), Młoda polska emigracja w UE jako przedmiot badań psychologicznych, socjologicznych i kulturowych. Artykuł pokonferencyjny EuroEmigranci.PL, Kraków 23-24.IX.2013 r, [dostęp: 11.01. 2017].

Tyralska-Wojtycza E, Widur A., Boba M. (2006), W trosce o etykę egzaminu gimnazjalnego, „Egzamin”, nr 7.

Walczak B. (2008), Społeczne, edukacyjne i wychowawcze konsekwencje migracji rodziców i opiekunów prawnych uczniów szkół podstawowych, gimnazjalnych i ponadgimnazjalnych. Pedagogium Wyższa Szkoła Pedagogiki Resocjalizacyjnej w Warszawie. Raport techniczny, [dostęp: 11.01. 2017].

Zarycki T. (1996), Polityczne profile regionów, [w:] Oblicza polskich regionów. Studia Regionalne i Lokalne, red. B. Jałowiecki, t. 50, Warszawa.

\section{SUMMARY}

\section{Educational achievements of students in Podlaskie Voivodeship in the context of other regions}

This paper compare educational achievements of students in Podlaskie Voivodeship in the context of other regions of Poland. As has been shown in previous research students is southern, central and eastern Poland (Małopolskie, Mazowieckie, Podlaskie, Lodzkie, Podkarpackie, Świętokrzyskie) score higher on external exit exams compared to student from western regions. Among the other factors, the size of the differences depends on the exam subject - it is larger for mathematics, but blurs in computer science and nonsexist in English. Educational advantage of Podlaskie Voivodeship disappear when percent of population with tertiary education is analyze. Three main hypothesis has been discussed to explain those differences: demographical, exam frauds and cultural impacts.

KEYWORDS: education, Podlaskie Voivodeship, Poland, school achievement 